\title{
Internal Risk Financing with Special Reference to Contingency Funds
}

\section{F J Mostert}

Department of Business Management, University of Stellenbosch

\begin{abstract}
Enterprises can manage risks in two fundamental ways, namely by physical risk control and by risk financing. The latter comprises external and internal risk financing. As this paper focuses on the latter of these concepts, due attention is paid to the main forms of internal risk financing. Charging losses to current operating profit, arranging loan facilities and implementing equity financing programmes are different forms of internal risk financing. The nature, advantages and various types of captive insurance companies are considered as holding companies can utilise this form of internal risk financing. Special attention is paid to the use of contingency funds as a way of internal risk financing by applying a modelling approach. The conclusions reached should be valuable to business enterprises in particular, but also to non-profit organisations and individuals.
\end{abstract}

JEL G13

\section{INTRODUCTION}

For the purpose of risk management, risks are defined as uncertain future events with possible detrimental results that need continuity planning (Savage, 2002: 254-61). Risks can be managed by enterprises in two fundamental ways, namely by means of physical risk control or by utilising risk financing. Risk avoidance and risk reduction are the main methods for applying physical risk control, while risk financing represents an attempt to provide the necessary financing capacity/funding to counter possible negative effects of risks, which can either be arranged externally or internally (Schneier \& Miccolis, 1998: 10-14).

External risk financing focuses primarily on obtaining insurance from a shortterm insurer or professional reinsurer, or by outsourcing/transferring the business activities concerned in order to avoid the possible detrimental results thereof (Preston \& Thomas, 2002: 66-8; Bowers, 1999: 30-1). Firms and insureds who are more at risk and do not have the necessary financial strength 
tend to choose insurance, especially during soft market cycles when the insurance rates and conditions are favourable.

The choice of internal risk financing will depend inter alia on the objectives of the enterprise, the nature of the operations, the prevailing market conditions, the enterprise's potential accumulation of risk, and the management's attitude towards risk (Gjertsen, 1997: 37-8). Self-insurance may also lead to better loss control by an enterprise (Bradford, 1999a: 3-5). Internal risk financing can take various forms, mainly by charging losses to current operating profit, by arranging loan facilities, by implementing an equity financing programme, by utilising captive insurance companies, or by establishing a contingency fund (Diacon \& Carter, 1992: 82). These forms of internal financing will receive due attention in what follows.

\section{OBJECTIVE OF THE RESEARCH}

The development of an overall risk management strategy by an enterprise is required before risks can be addressed. The objective of this research paper is the improvement of financial decision making by enterprises when internal risk financing is chosen as the appropriate way to manage risks. In order to achieve this objective, taking cognisance of the various forms of internal risk financing is essential as the starting phase. Thereafter, a modelling approach is applied in order to construct a contingency fund and to determine the feasibility of such a way of internal risk financing. The conclusions reached should be valuable to business enterprises in particular, but also to non-profit organisations and individuals.

\section{VARIOUS FORMS OF INTERNAL RISK FINANCING}

An enterprise should start by developing an overall risk management strategy. When opting for internal risk financing in the employment of the strategy, the following five forms present the main choices:

\subsection{Charging losses to current operating profit}

The detrimental financial results of risk situations can be deducted from the current operating profit of enterprises. In this way, the enterprise receives a tax benefit as the taxable profit, as well as the taxation payable, decreases. The actual size of a loss after taxation is therefore equal to:

Gross loss x $(1-t)$

where: $\quad t=$ the applicable tax rate. 
The main disadvantage of this form of internal risk financing relates to the fact that the loss is determined by using the book value of the assets which were lost and that the replacement value of the assets is not taken into consideration. This form of internal risk financing may be applicable when relatively small losses are considered, but large detrimental results will need a more appropriate form of internal risk financing.

\subsection{Loan facilities}

Enterprises with acceptable credit risk and sound solvency may consider this form of internal risk financing (Altman \& Saunders, 1997: 1721-40). Two kinds of approaches are evident, namely that the loans may be arranged before or after the occurrence of the loss situation. Although an arrangement before the loss situation occurs looks very attractive, one has to take into account that an availability fee will be charged in the meantime and that the actual interest rate will be determined when the loan is granted. Redemption conditions may also be unfavourable.

It is realistic to accept that an enterprise's solvency may deteriorate after a loss situation has occurred and that applying for a loan afterwards will inevitably lead to high interest rates and strict repayment stipulations. Furthermore, research has shown that due to the asymmetric nature of loan contracts, banks are not properly equipped to deal with systematic risk (for example real exchange rate fluctuations) (Kildegaard \& Williams, 2002: 357). Due to asymmetric contracts, banks are not in a position to diversify across borrowers, and therefore should find already diversified borrowers. For a non-diversified enterprise, this result may provide an important obstacle to obtaining loan facilities.

\subsection{Equity financing programmes}

An equity financing programme creates a situation in which an investment company concludes an agreement to subscribe to a predetermined number of ordinary or preference shares of another company at a predetermined favourable price in the event of a specified catastrophe (Zolkos, 1996: 1-3). The enterprise that is impaired will therefore receive a guaranteed amount of equity that will not only improve the liquidity, but also the solvency of the enterprise.

It is obvious, however, that an equity financing programme will bring about periodic charges for the company, which are payable to the investment company in exchange for the benefit of having an equity financing programme in place. Furthermore, in the event of issuing ordinary shares to the investment company, 
there may be a shift in the control of the damaged company, while the net asset value of the shares may also be diluted.

\subsection{Captive insurance companies}

A captive insurance company actually is the subsidiary of one (or more than one) holding company and is usually operated by experienced insurance professionals. As the subsidiary acts as the insurer of the holding company, it is reasonable to assume that the insurance business provided by the holding company or companies should be adequate to justify the economic existence of the captive insurance company. Research showed that there is no evidence to suggest that the establishment of a captive insurance company changes the systematic, unsystematic and financial risks posture of a holding company (Adams \& Hillier, 2000: 1804). It is believed that the holding company tends to have a superior loss ratio and that the captive insurance company can therefore manage the particular risks.

The establishment of a captive insurance company provides several potential advantages to a holding company (Diacon \& Carter, 1992: 82-3). The insurance provided by the subsidiary to the holding company may be more flexible than that which may be available in the insurance market. The cost of insurance may also be lower, as the underwriting profit made by the captive insurance company may be distributed to the holding company by means of a dividend (McDonald, 2001: 9). Furthermore, the captive insurance company may provide coverage that may not be available in the insurance market. A captive insurance company has direct access to the reinsurance markets, but due to the law of large numbers, the reinsurance may be more expensive (Anderson, 2001: 35; Bradford, 1999b: 36). Tax benefits (which will be discussed later) may also emerge from the application of this form of internal risk financing. The utilisation of captive insurance companies is very popular when the insurance cycle hardens and the insurance rates are increased (Howard, 2001: 7). The control that the holding company has over the captive insurance company adds value to the situation (Zolkos, 2000: 3-4).

Three prominent types of captive insurance companies will be discussed (although there are other types as well (Costle \& Schauer, 2000: 310-11)), the first being onshore companies. The insurance premiums paid by the holding company to the subsidiary may be deducted for tax purposes, as the subsidiary will be taxed by the local authorities on the profit made during a financial year. As dividends paid by the subsidiary to the holding company are based on profit after taxation, the dividends will usually not be taxable in the hands of the holding company (Huxham \& Haupt, 2000: 222). The local authorities are at peace with this type of captive insurance company. 
The second type of captive insurance company is known as an offshore company (Insurance Advocate, 2000: 30). As the subsidiary is established in another country (and often in a tax haven (Hampton \& Christensen, 2002: 1660)), the profit of the subsidiary cannot be taxed by the local authorities. If the holding company wants to deduct the insurance premiums paid to the offshore captive insurance company for tax purposes, the holding company has to convince the local authorities that it does not involve a scheme to avoid taxation, but is merely part of a comprehensive risk management strategy.

The last type of subsidiary is called a cell captive insurance company as it consists of various "cells" which are independent when insolvency occurs (Pilla, 2001: 86; Veysey, 2000: 33-4). Each holding company can obtain a particular cell and can canalise its insurance needs through it. The cell captive insurance company however is registered as one insurer and the administration is undertaken by a centralised organisation. It may therefore be less expensive for a holding company to run a particular cell of a cell captive insurance company than to run its own captive insurance company.

\subsection{Contingency funds}

A contingency fund represents the investment of money in a particular fund with the sole purpose that the accumulated amount will immediately be available when a loss situation occurs (Zolkos, 1998: 3-4). The contingency fund is the property of the enterprise and the enterprise consequently controls the application of the accumulated funds. A contingency fund is created by application of two sources of financing, viz.:

(1) Periodic payments made by the enterprise, which should be increased periodically by a growth rate in an attempt to provide for the higher replacement value of the property. As these payments are not tax deductible, an enterprise applies funds that are available after taxation. To the contrary, although short-term insurance premiums paid by enterprises are tax deductible, the insurance premiums may actually be higher due to taxes levied on the insurance industry (Huxham \& Haupt, 2000: 70; Ke, Petroni \& Shackelford, 2000: 99-120).

(2) Periodic interest allocations received by the enterprise based on the accumulated amount of the contingency fund. The interest received by the enterprise will usually be taxed according to the definition of gross income in the Income Tax Act (Huxham \& Haupt, 2000: 6).

As already indicated, the sole purpose of a contingency fund is to provide an accumulated amount when a loss situation occurs. The amount needed in a particular case will be determined by the following two factors: 
(1) The replacement value of the assets concerned when the contingency fund is actually established.

(2) The annual inflation rate which is applicable on the particular kinds of assets as price increases have different impacts on different assets.

It is of prime importance that the accumulated amount of a contingency fund should continuously be compared with the current replacement value of the particular asset. Should the replacement value of the asset exceed the accumulated amount of the contingency fund, financial distress may prevail on the occurrence of a detrimental event. A possible deficit in the event of a loss situation may lead to the reduction of the enterprise's activities and the abolishment of potential investment opportunities. It is therefore often necessary to combine a contingency fund with other forms of risk financing in order to cover asset losses sufficiently.

\section{MODELLING APPROACH FOR A CONTINGENCY FUND}

A modelling approach for a contingency fund is presented in Table 1, where the following six independent variables are used:

(1) Interest rate after taxation (denoted by $i$ ) $=6$ per cent per annum;

(2) Initial annual payment (payable in advance) (denoted by $P$ ) $=\mathrm{R} 1200$ at the starting point;

(3) Growth rate of annual payments (denoted by $g$ ) $=9$ per cent per annum;

(4) Initial replacement value of property (denoted by $V$ ) $=\mathrm{R} 100000$;

(5) Inflation rate applicable to property (denoted by $f$ ) $=8$ per cent per annum; and

(6) Number of years (denoted by $n$ ).

The initial annual payment of R1 200 approximately represents the annual insurance premium for the content of houses with a replacement value of R100 000 in low risk areas (Brandsen, 2002: personal interview). The content of houses was chosen for illustration purposes because the level of risk is regarded as higher than that of buildings, but lower than the risk associated with motor vehicles. The annual payments are payable in advance as the same condition usually applies in the case of insurance premiums. 
Table 1 Comparison of the final value of a contingency fund and the replacement value of property in the following conditions:

Interest rate after taxation $(i)=6$ per cent per annum; Initial payment $(P)=\mathrm{R} 1200$ at the starting point;

Growth rate of payments $(g)=9$ per cent per annum;

Initial replacement value of property $(V)=\mathrm{R} 100000$; and Inflation rate applicable to property $(f)=8$ per cent per annum

\begin{tabular}{|c|c|c|c|}
\hline $\begin{array}{c}\text { End of } \\
\text { year }\end{array}$ & $\begin{array}{c}\text { Final value of } \\
\text { contingency fund }\end{array}$ & $\begin{array}{c}\text { Replacement } \\
\text { value of property }\end{array}$ & $\begin{array}{c}\text { Column (b) as \% of } \\
\text { column (c) }\end{array}$ \\
\hline (a) & (b) & (c) & (d) \\
\hline 0 & 1,200 & 100,000 & 1.20 \\
\hline 1 & 1,272 & 108,000 & 1.18 \\
\hline 2 & 2,735 & 116,640 & 2.34 \\
\hline 3 & 4,410 & 125,971 & 3.50 \\
\hline 4 & 6,322 & 136,049 & 4.65 \\
\hline 5 & 8,497 & 146,933 & 5.78 \\
\hline 6 & 10,964 & 158,687 & 6.91 \\
\hline 7 & 13,755 & 171,382 & 8.03 \\
\hline 8 & 16,905 & 185,093 & 9.13 \\
\hline 9 & 20,454 & 199,900 & 10.23 \\
\hline 10 & 24,444 & 215,892 & 11.32 \\
\hline 11 & 28,922 & 233,164 & 12.40 \\
\hline 12 & 33,940 & 251,817 & 13.48 \\
\hline 13 & 39,554 & 271,962 & 14.54 \\
\hline 14 & 45,827 & 293,719 & 15.60 \\
\hline 15 & 52,827 & 317,217 & 16.65 \\
\hline 16 & 60,630 & 342,594 & 17.70 \\
\hline 17 & 69,318 & 370,002 & 18.73 \\
\hline 18 & 78,982 & 399,602 & 19.77 \\
\hline 19 & 89,721 & 431,570 & 20.79 \\
\hline 20 & 101,644 & 466,096 & 21.81 \\
\hline 21 & 114,872 & 503,383 & 22.82 \\
\hline 22 & 129,535 & 543,654 & 23.83 \\
\hline 23 & 145,776 & 587,146 & 24.83 \\
\hline 24 & 163,755 & 634,118 & 25.82 \\
\hline 25 & 183,643 & 684,848 & 26.82 \\
\hline 26 & 205,630 & 739,635 & 27.80 \\
\hline 27 & 229,924 & 798,806 & 28.78 \\
\hline 28 & 256,751 & 862,711 & 29.76 \\
\hline
\end{tabular}


Table 1 continued

\begin{tabular}{||c|c|c|c||}
\hline $\begin{array}{c}\text { End of } \\
\text { year }\end{array}$ & $\begin{array}{c}\text { Final value of } \\
\text { contingency fund }\end{array}$ & $\begin{array}{c}\text { Replacement } \\
\text { value of property }\end{array}$ & $\begin{array}{c}\text { Column (b) as \% of } \\
\text { column (c) }\end{array}$ \\
\hline 29 & 286,361 & 931,727 & 30.73 \\
\hline 30 & 319,026 & $1,006,266$ & 31.70 \\
\hline 31 & 355,044 & $1,086,767$ & 32.67 \\
\hline 32 & 394,742 & $1,173,708$ & 33.63 \\
\hline 33 & 438,477 & $1,267,605$ & 34.59 \\
\hline 34 & 486,641 & $1,369,013$ & 35.55 \\
\hline 35 & 539,662 & $1,478,534$ & 36.50 \\
\hline 36 & 598,008 & $1,596,817$ & 37.45 \\
\hline 37 & 662,193 & $1,724,563$ & 38.40 \\
\hline 38 & 732,775 & $1,862,528$ & 39.34 \\
\hline 39 & 810,369 & $2,011,530$ & 40.29 \\
\hline 40 & 895,645 & $2,172,452$ & 41.23 \\
\hline
\end{tabular}

The results of column (b) in Table 1 are calculated by using the formula for the final value of a geometric progression/series (Conradie \& Schoeman, 2001: 86), viz.:

$$
P(1+i)\left[(1+i)^{n}-(1+g)^{n}\right] /(i-g)
$$

where: $\quad n=$ number of years, $i \neq g$ and the annual payments are payable in advance.

The results of column (c) is arrived at by applying the following well-known formula:

$$
V(1+f)^{n}
$$

Column (d) shows the final value of the contingency fund as a percentage of the replacement value of the property at the end of each year. It is clear that, by applying the given values of the independent variables, the contingency fund will only be able to provide 41,23 per cent of the replacement value of the property after 40 years have expired.

The same exercise was repeated several times and the results are presented in the three figures provided below. Annual interest rates of 6, 10, 14 and 18 per cent are used in all three figures. The annual inflation rate applicable to property, according to Figure 1, equals 6 per cent, that of Figure 2 is 10 per cent, while an annual inflation rate of 14 per cent is applied in Figure 3. The annual growth rate of the annual payments (payable in advance) remains constant at 9 per cent throughout. 
Figure 1 Value of contingency fund as percentage of the replacement value of property when the growth rate of annual payments and inflation rate are respectively 9 per cent and 6 per cent per annum and different annual interest rates apply

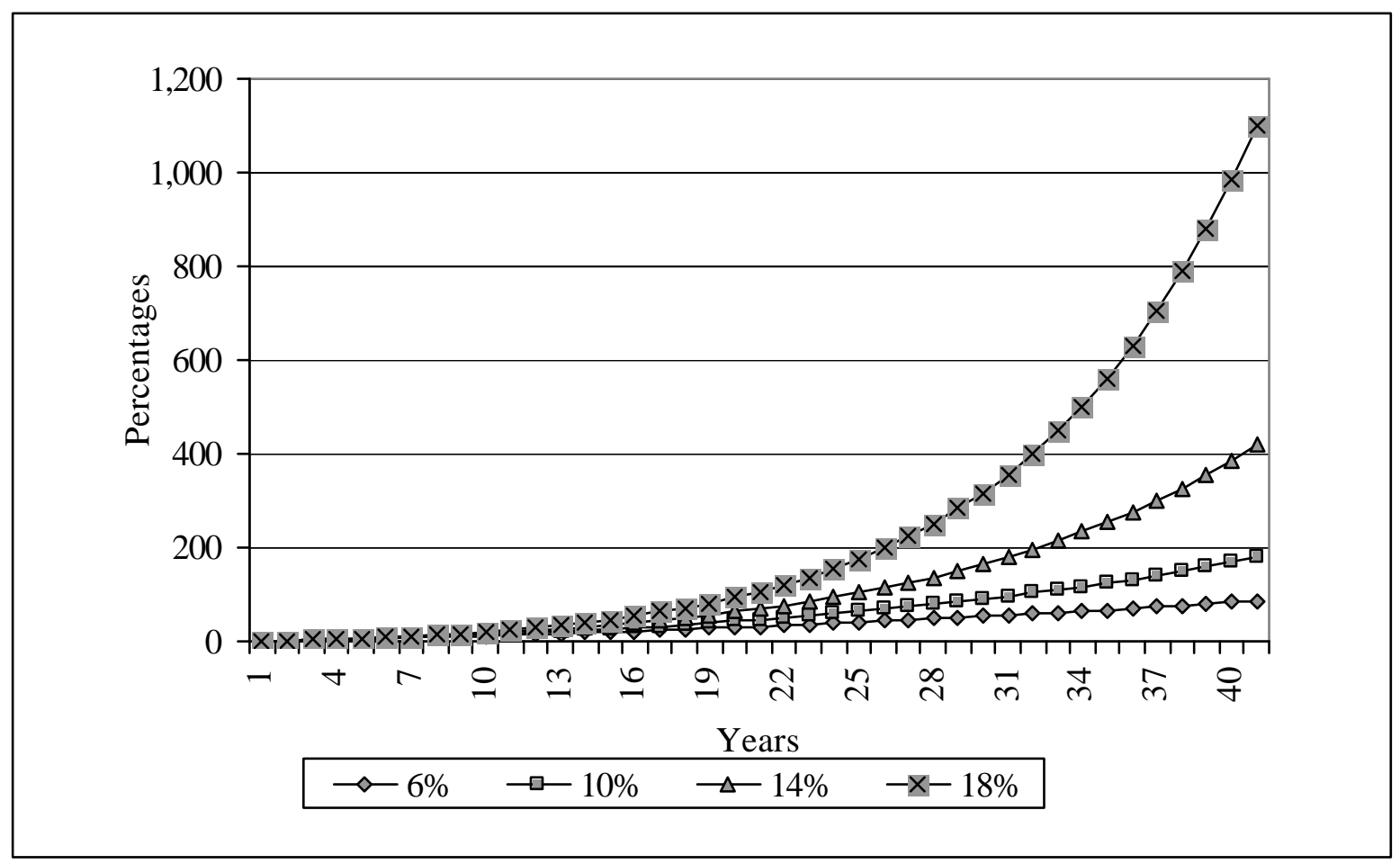

Figure 2 Value of contingency fund as percentage of the replacement value of property when the growth rate of annual payments and inflation rate are respectively 9 per cent and 10 per cent per annum and different annual interest rates apply

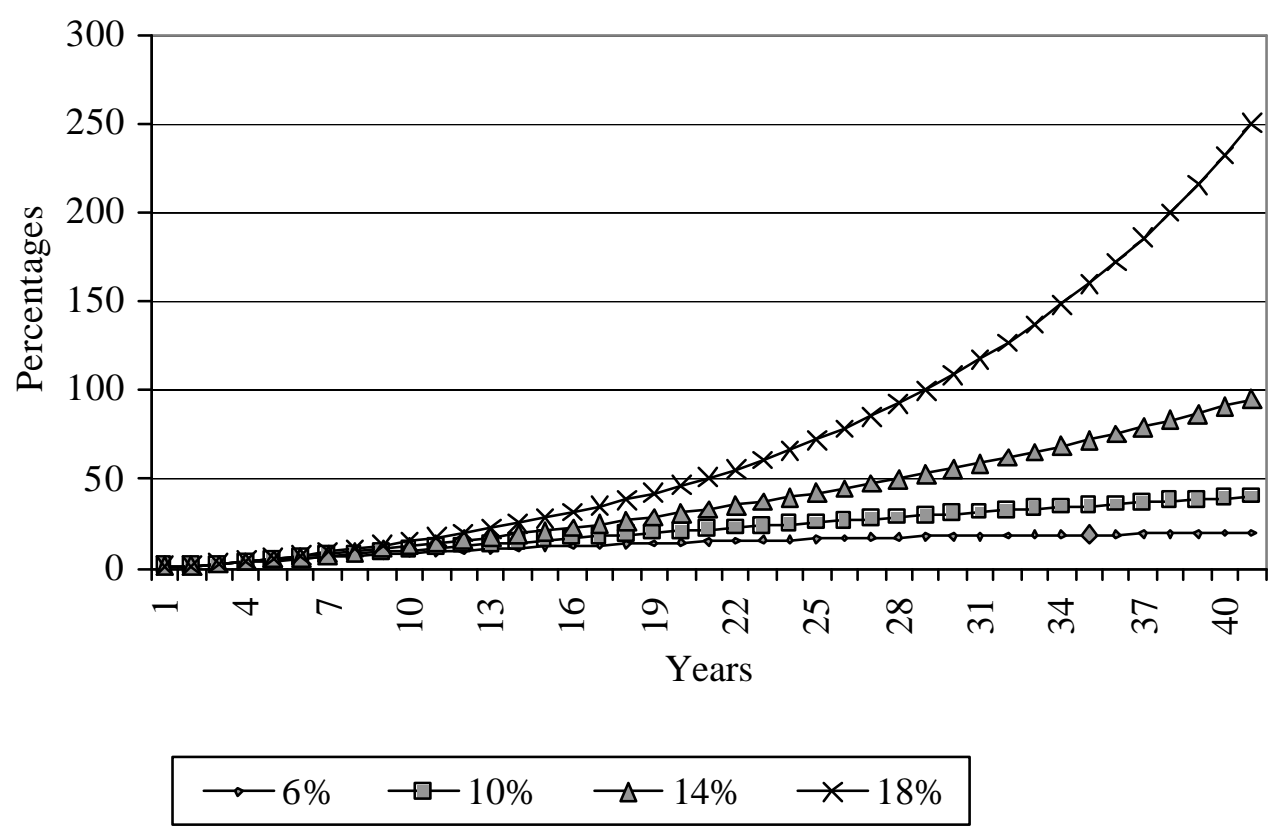


The preceding figures lead to the following results:

Figure 3 Value of contingency fund as percentage of the replacement value of property when the growth rate of annual payments and inflation rate are respectively 9 per cent and 14 per cent per annum and different annual interest rates apply

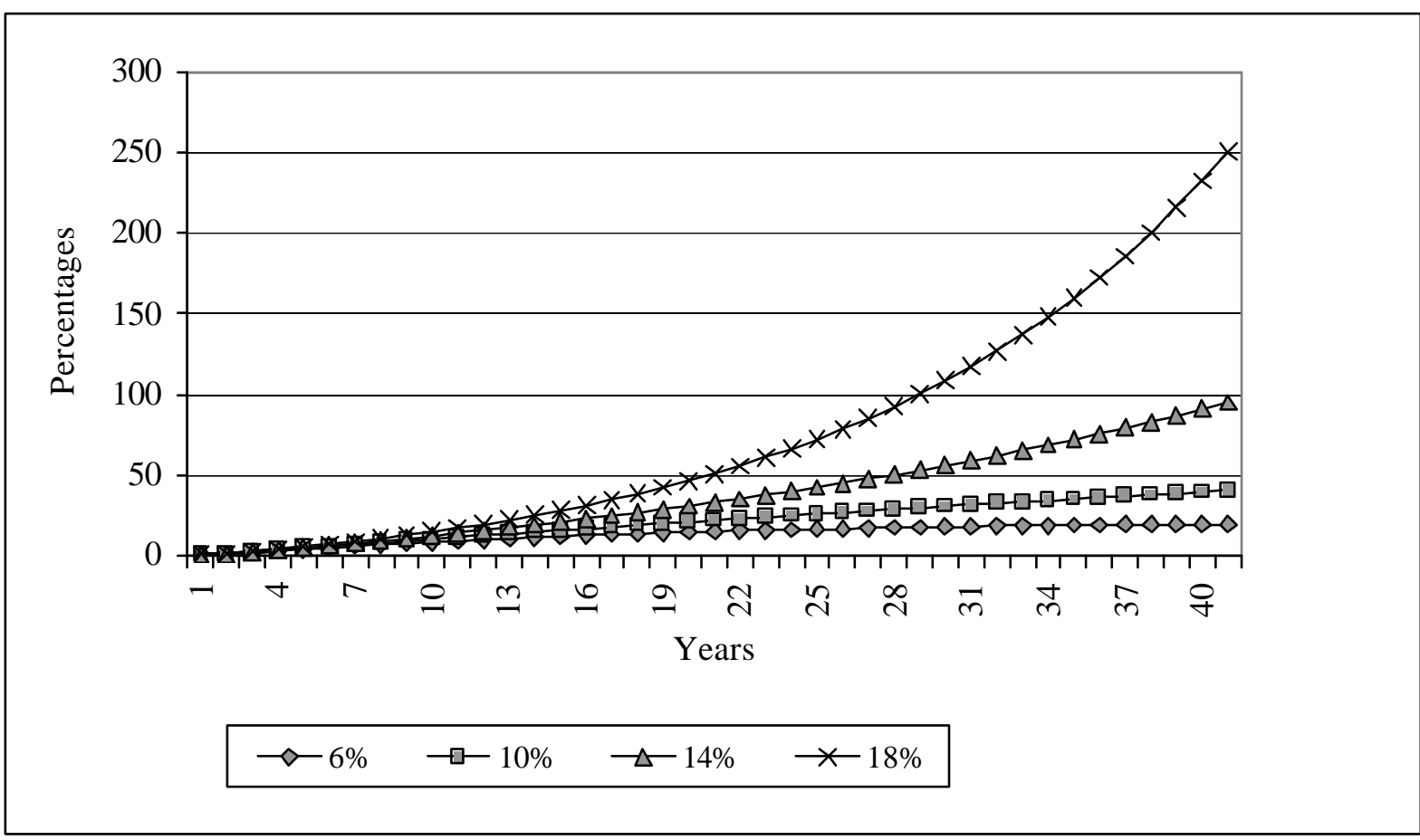

(1) In only four of the 12 situations which are presented in the figures, the value of the contingency fund as a percentage of the replacement value of property could equal or exceed the 100 per cent level during the period of 40 years. Such situations occur when the interest rate, growth rate of the annual payments and the inflation rate respectively are as follows:

$\geq 10$ per cent, 9 per cent, 6 per cent per annum; and 18 per cent, 9 per cent, 10 per cent per annum.

When the location of the assets of an enterprise is geographically diversified, distribution of the associated risk takes place. This form of internal risk financing may then be acceptable, as full replacement value of all the assets may not be necessary.

(2) When the annual interest rate increases by only four percentage points (i.e. from 6 to 10 to 14 to 18 per cent), the value of the contingency fund as a percentage of the replacement value of property at the end of 40 years, each time increases by more than 100 per cent for a given annual 
inflation rate. In the long run, the level of the annual interest rate is therefore of prime importance for the feasibility of a contingency fund.

(3) When the annual inflation rate increases by only four percentage points (i.e. from 6 to 10 to 14 per cent), the value of the contingency fund as a percentage of the replacement value of property at the end of 40 years, each time decreases by more than 75 per cent for a given annual interest rate. The extent of the annual inflation rate over the long term therefore plays a significant role when the sufficiency of a contingency fund is assessed.

(4) The value of the contingency fund as a percentage of the replacement value of property shows an increasing tendency over the period of 40 years, except for two situations in Figure 3. These situations occur when annual interest rates of respectively 6 and 10 per cent are applied and the growth rate of the annual payments remains at 9 per cent per annum, while the annual inflation rate equals 14 per cent. In these two cases, a turning point in the results is experienced after respectively 18 and 25 years have expired. It seems that, in these cases, the annual interest rate, as well as the growth rate of the annual payments, could not deal with the impact of the high annual inflation rate in the long run. The fact that the inflation rate exceeds the annual interest rate and annual growth rate cannot provide an explanation for the turning point in the results, as it does not occur when the interest rate, growth rate of the annual payments and inflation rate is respectively 6, 9, 10 per cent per annum, as in Figure 2. The turning points in the results provide an opportunity for future research.

In order to assess whether the value of the contingency fund is adequate to provide for the replacement value of property for a particular situation, an alternative approach can be used. Given the five remaining independent variables of the modelling approach, the annual inflation rate of property provided for by the contingency fund is determined by applying the following equation (which is derived by using formulas 2 and 3):

$$
f=\left[P(1+i)\left\{(1+i)^{n}-(1+g)^{n}\right\} /\{(i-g) \times V\}\right]^{1 / n}-1
$$

where the symbols have the same meaning as before.

The results obtained when the initial replacement value of the property equals R100 000, the first annual payment (payable in advance) to the contingency fund is equal to R1 200 and thereafter increases annually at a growth rate of 9 
per cent, and different annual interest rates and periods are applied, are presented in Table 2.

Table 2 Annual inflation rates of property provided for by a contingency fund, classified according to different annual interest rates of the contingency fund and different periods

\begin{tabular}{||l|c|c|c|c|c|c|c||}
\hline & \multicolumn{6}{|c|}{ Annual interest rates of contingency fund (percentage) } \\
\hline Periods & 6 & 8 & 10 & 12 & 14 & 16 & 18 \\
\hline 5 years & $-38,9$ & $-38,2$ & $-37,6$ & $-36,9$ & $-36,2$ & $-35,5$ & $-34,8$ \\
\hline 10 years & $-13,1$ & $-12,3$ & $-11,4$ & $-10,5$ & $-9,5$ & $-8,6$ & $-7,7$ \\
\hline 15 years & $-4,2$ & $-3,2$ & $-2,3$ & $-1,3$ & $-0,3$ & 0,7 & 1,8 \\
\hline 20 years & 0,1 & 1,0 & 2,0 & 3,0 & 4,1 & 5,2 & 6,4 \\
\hline 25 years & 2,5 & 3,4 & 4,4 & 5,4 & 6,5 & 7,7 & 8,9 \\
\hline 30 years & 3,9 & 4,9 & 5,9 & 6,9 & 8,1 & 9,3 & 10,6 \\
\hline 35 years & 4,9 & 5,8 & 6,8 & 7,9 & 9,1 & 10,4 & 11,7 \\
\hline 40 years & 5,6 & 6,5 & 7,5 & 8,6 & 9,9 & 11,2 & 12,5 \\
\hline \hline
\end{tabular}

The preceding table leads to the following important results:

(1) The negative inflation rates in the table indicate that the initial replacement value of the property should decrease annually by that percentage if the contingency fund has to provide full indemnity. No provision for possible price increases of the property is therefore available in these cases.

(2) It is important to note that, even when the annual interest rate of the contingency fund is as high as 18 per cent and the payments to the contingency fund increase annually at a growth rate of 9 per cent, the contingency fund will be in a position to provide for an annual inflation rate of only 12,548 per cent after 40 years have expired. The reason lies in the fact that the contingency fund starts with an initial payment of R1 200 while the initial replacement value of the property equals R100 000.

(3) When the annual interest rate of a contingency fund remains constant, the annual inflation rate provided for by the contingency fund increases annually as the period increases, but the increments show a decreasing tendency. For example, with an annual interest rate of 10 per cent, the annual inflation rate provided for by the contingency fund increases by an increment of 2,4 percentage points (from 2,0 to 4,4 per cent) when the period increases from 20 to 25 years; by an increment of only 1,5 percentage points when the period increases from 25 to 30 years; and by 
an increment of only 0,9 percentage points when the period increases from 30 to 35 years.

\section{CONCLUSIONS}

The following conclusions are reached in respect of the various forms of internal risk financing:

(1) Charging losses to current operating profit, arrangement of loan facilities and implementation of equity financing programmes are not necessarily without disadvantages. Enterprises should therefore be careful when relying on these forms of internal risk financing only.

(2) Onshore, offshore and cell captive insurance companies are important facilities for internal risk financing which should be considered by enterprises due to the number of advantages which they provide.

(3) A contingency fund often does not provide 100 per cent or more of the replacement value of property over a period of 40 years. When the location of the assets of an enterprise is geographically diversified, distribution of the associated risk takes place. This form of internal risk financing may then be acceptable, as full replacement value of all the assets may not be necessary.

(4) It has been determined that, in the long run, the level of the annual interest rate is of prime importance for the feasibility of a contingency fund. The extent of the annual inflation rate of the assets concerned over the long term also plays a significant role when the sufficiency of a contingency fund is assessed. The value of the contingency fund as a percentage of the replacement value of property usually shows an increasing tendency over the long term, although a turning point in the results may sometimes be experienced.

(5) It is important to note that, even when the annual interest rate of the contingency fund is as high as 18 per cent and the payments to the contingency fund increase annually at a growth rate of 9 per cent, the contingency fund will be in a position, after 40 years have expired, to provide for an annual inflation rate of only 12,548 per cent. The reason lies in the fact that the contingency fund starts with a single initial payment, while the initial replacement value of the property represents a significant amount. 
(6) When the annual interest rate and the annual growth rate of the annual payments of a contingency fund remain constant, the annual inflation rate provided for by the contingency fund increases annually as the period increases, but the increments show a decreasing tendency.

The four preceding conclusions culminate in the observation that an enterprise should take the following aspects into consideration when assessing the feasibility of a contingency fund for its own circumstances:

(a) whether the assets of the particular enterprise are geographically diversified;

(b) the level of the expected annual interest rate of the contingency fund in the long run;

(c) the extent of the anticipated annual inflation rate of the assets concerned over the long term;

(d) the fact that the value of the contingency fund initially has a significant backlog compared to the replacement value of the assets; and that

(e) when the annual interest rate and the annual growth rate of the annual payments of a contingency fund remain constant, the annual inflation rate provided for by the contingency fund increases degressively as the period increases.

\section{REFERENCES}

1 ADAMS, M. \& HILLIER, D. (2000) "The effect of captive insurer formation on stock returns: An empirical test from the UK", Journal of Banking \& Finance, 24(11): 1787-807.

2 ALTMAN, E.I. \& SAUNDERS, A. (1997) "Credit risk measurement: developments over the last 20 years", Journal of Banking \& Finance, 21(11-12): 1721-42.

3 ANDERSON, M.E. (2001) "Pickup trucks and captives", Best's Review, 101(11): 35-8.

4 BOWERS, B. (1999) "Swiss recentralized alternative risk transfer", Best's Review / Property-Casualty Insurance Edition, 99(10): 30-1.

5 BRADFORD, M. (1999a) "Captives driving growth in self-insurance vehicles", Business Insurance, 33(7): 3-5.

6 BRADFORD, M. (1999b) "Reinsurance troubles may await captives", Business Insurance, 33(49): 36.

7 BRANDSEN, A. (2002) Personal interview, Alexander Forbes Risk Services, Stellenbosch, 19 March.

8 CONRADIE, W.J. \& SCHOEMAN, A. (2001) Renterekening met Finansiële Sakrekenaars, (3rd print), Stellenbosch: Universiteit van Stellenbosch Drukkery. 
9 COSTLE, E.R. \& SCHAUER, K.A. (2000) "The captive alternative: A regulatory perspective", Journal of Insurance Regulation, 19(2): 304-22.

10 DIACON, S.R. \& CARTER, R.L. (1992) Success in Insurance (3 ${ }^{\text {rd }}$ ed.) London: John Murray.

11 GJERTSEN, L.A. (1997) "Risk financing for the middle market", National Underwriter, 101(17): 37-38.

12 HAMPTON, M.P. \& CHRISTENSEN, J. (2002) "Offshore pariahs? Small island economies, tax havens, and the re-configuration of global finance", World Development, 30(9): 1657-73.

13 HOWARD, L.S. (2001) "Global Captive Use Grows in Hard Market." National Underwriter, 105(11): 7 \& 25.

14 HUXHAM, K. \& HAUPT, P. (2000) Aantekeninge oor Suid-Afrikaanse Inkomstebelasting, (19th ed.) Rogge Bay: H \& H Publications.

15 INSURANCE ADVOCATE (2000) "Risk management consultant predicts increased use of offshore captives, including segregated account companies", quoted in: Insurance Advocate, 111(50): 30.

16 KE, B., PETRONI, K.R. \& SHACKELFORD, D.A. (2000) "The impact of state taxes on self-insurance", Journal of Accounting \& Economics, 30(1): 99-122.

17 KILDEGAARD, A. \& WILLIAMS, P. (2002) "Banks, systematic risk, and industrial concentration: Theory and evidence", Journal of Economic Behavior \& Organization, 47(4): 345-58.

18 McDONALD, C. (2001) "Captives 101: Three success stories", National Underwriter, 105(21): 9.

19 PILLA, D. (2001) “Captivating Growth”, Best's Review, 102(1): 85-6.

20 PRESTON, L.W. \& THOMAS, B.B. (2002) "Reassessing the value of insurance”, Best's Review / Property-Casualty Insurance Edition, 103(4): 66-8.

21 SAVAGE, M. (2002) "Business continuity planning", Work Study, 51(5): 254-61.

22 SCHNEIER, R. \& MICCOLIS, J. (1998) "Enterprise risk management", Strategy \& Leadership, 26(2): 10-4.

23 VEYSEY, S. (2000) "Will new options supplant captives?", Business Insurance, 34(23): 33-4.

24 ZOLKOS, R. (1996) "Alternative risk financing grows", Business Insurance, 30(50): 1-3.

25 ZOLKOS, R. (1998) "Captives may be used to tap capital markets", Business Insurance, 32(48): 3-4.

26 ZOLKOS, R. (2000) "Role of captives changes with market", Business Insurance, 34(48): 3-4. 